\title{
Correction to: Phenotype and multi-omics comparison of Staphylococcus and Streptococcus uncovers pathogenic traits and predicts zoonotic potential
}

\author{
Niels A. Zondervan ${ }^{1}$, Vitor A. P. Martins dos Santos ${ }^{1,2}$, Maria Suarez-Diez ${ }^{1 \dagger}$ and Edoardo Saccenti ${ }^{1 *+}$
}

Correction to: BMC Genomics 22, 102 (2021)

https://doi.org/10.1186/s12864-021-07388-6

Following publication of the original article [1], it was reported that there was a missing reference in the Methods section and should have been reference [2] at the end of the following sentence:

The GNU "parallel" package was used to perform all of the above steps in parallel [2].

This reference has been inserted in the original article, the subsequent references have been renumbered, and the original article has been corrected.

\section{Author details}

'Laboratory of Systems and Synthetic Biology, Wageningen University \& Research, Stippeneng 4, 6708 WE Wageningen, Netherlands. ${ }^{2}$ LifeGlimmer GmBH, Markelstraße 38, 12163 Berlin, Germany.

Published online: 25 May 2021

\section{References \\ 1. Zondervan NA, Martins dos Santos VAP, Suarez-Diez M, et al. Phenotype and multi-omics comparison of Staphylococcus and Streptococcus uncovers pathogenic traits and predicts zoonotic potential. BMC Genomics. 2021;22: 102. https://doi.org/10.1186/s12864-021-07388-6. \\ 2. Tange O. Gnu parallel-the command-line power tool. USENIX Mag. 2011; 36(1):42-7.}

The original article can be found online at https://doi.org/10.1186/s12864021-07388-6.

* Correspondence: edoardo.saccenti@wur.nl

${ }^{\dagger}$ Maria Suarez-Diez and Edoardo Saccenti these authors jointly supervised this work.

${ }^{1}$ Laboratory of Systems and Synthetic Biology, Wageningen University \& Research, Stippeneng 4, 6708 WE Wageningen, Netherlands

Full list of author information is available at the end of the article

(c) The Author(s). 2021 Open Access This article is licensed under a Creative Commons Attribution 4.0 International License, which permits use, sharing, adaptation, distribution and reproduction in any medium or format, as long as you give appropriate credit to the original author(s) and the source, provide a link to the Creative Commons licence, and indicate if changes were made. The images or other third party material in this article are included in the article's Creative Commons licence, unless indicated otherwise in a credit line to the material. If material is not included in the article's Creative Commons licence and your intended use is not permitted by statutory regulation or exceeds the permitted use, you will need to obtain permission directly from the copyright holder. To view a copy of this licence, visit http://creativecommons.org/licenses/by/4.0/. The Creative Commons Public Domain Dedication waiver (http://creativecommons.org/publicdomain/zero/1.0/) applies to the data made available in this article, unless otherwise stated in a credit line to the data. 